\title{
Effect of Science Teaching Enriched with Technological Practices on Attitudes of Secondary School $7^{\text {th }}$ Grade Students towards Science Course
}

\author{
Halil Ibrahim Yildirim*, Onder Sensoy \\ Department of Science Education, Gazi Education Faculty, Gazi University, Ankara, Turkey
}

Copyright $(2018$ by authors, all rights reserved. Authors agree that this article remains permanently open access under the terms of the Creative Commons Attribution License 4.0 International License

\begin{abstract}
Purpose of this research is to examine effect of science teaching enriched with technological practices on attitude levels of secondary school $7^{\text {th }}$ grade students towards science course. Execution step of the research was performed on $7^{\text {th }}$ grade students attending to a government secondary school in Turkey in the academic year of 2015 and completed in 13 weeks. Workgroup of the study had 74 students (control group $=38$, experiment group $=36$ ). "The Attitude towards Science Course Scale" was used to collect data. The scale having 5-point Likert grading structure was applied as pretest, posttest and follow-up test. Cronbach Alpha $(\alpha)$ reliability coefficient of the scale was 0.85 . The execution step of the study was performed by the same teacher in science courses of control and experiment groups. The control group was not subjected to any experimental process and a student centered education in line with the existing science course curriculum was offered. The experiment group received education in parallel to the curriculum but technologically enriched science education programs were included in the teaching process. The research concluded that attitude levels of the experiment group significantly increased and this increase was still preserved three months after completing the research.
\end{abstract}

Keywords Technology, Attitude, Science Teaching Enriched by Technological Practices, Attitude towards Science Course, Science Instruction

\section{Introduction}

Using technology in the learning - teaching process has become inevitable for improving efficiency of education in parallel to the developments experienced in information, communication and technology segments in the $21^{\text {st }}$ century $[1,2,3,4,5,6]$. Integrating technology into educational activities has never been this important and classrooms offer teaching and learning options to teachers and students through quick access to technologies and teaching materials [7]. Teaching processes applied in classrooms has started to be technology-supported when technology infiltrated into education environments [8]. Technologically enriched education includes interesting, interactive technological practices assuring student participation that might have positive effect on students' attitude towards the course.

\section{Attitude in Teaching}

It is seen that there is a wide range of studies arguing that attitude towards a course is one of the key affective factors having impact on teaching - learning process $[9,10,11,12$, 13, 14, 15]. Positive attitudes towards school and learning improve any student's knowledge acquisition, skill development abilities and motivation [16]. Attitude is one of the key factors determining students' achievements in science [17]. If students have positive attitude towards science, they might be more interested in this field and prefer professions related with science in the future [18]. The studies conducted by Mattern \& Schau [19] show that positive attitudes developed by students during student life have impact on working, doing researches in the field of science in future. Students' attitude towards science course has impact on levels of success in science $[13,20$, 21, 22, 23]. A study by Yildirim \& Kansiz [24] concluded that there is a significant relationship between frequency of using technological practices in teaching process and attitude towards science course, and interactive technological practices, which address differences in learning ways of students, must be used in the learning teaching process.

\section{Technology in Teaching}

In today's world, education and use of technology in education are two concepts that cannot be separated from 
each other $[25,26,27]$. Many researchers highlight that effective use of teaching technologies has the potential of improving education system $[28,29]$. In a world shaped by technology, we certainly acknowledge the importance we should attach to educating our students. Thus, if a student gets into the habit of applying and using technology directly on the education process, that student will not fall behind the times by using technology in daily life [30]. Individuals being more attentive to and sparing time for use of technology and computer in the education process are known to believe in themselves and have positive competencies [31]. To sum up, considering the today's technological advancements and increased importance of education, it has become inevitable to use technology for solving educational problems [3]. Purpose of technology based or technologically enriched learning environments is to achieve positive results through learning and teaching processes appealing to all students having different ways of learning [32].

In this context, technology should be used in the process of learning and teaching science, and technology should be integrated in education process by taking into consideration technological qualifications teachers and students have [33, 34]. Integrating technology into learning process means integrating technology into pedagogical content knowledge, in other words it means using Technological Pedagogical Content Knowledge (TPACK) in learning-teaching process. Yildiz [35] argues that teachers must have TPACK competence for successfully completing integration of technology into their courses. This research discusses teaching enriched with technological practices, i.e. TPACK - supported teaching in the education process.

\section{Technological Pedagogical Content Knowledge}

Today, technology has become a gradually expanding part of classrooms and thus teachers are expected to have technological knowledge as well as pedagogical and content knowledge [36]. Mishra \& Koehler [37] defined this knowledge as TPACK. As seen on the Ministry of National Education's "Draft National Teaching Strategy Statement" and Turkish Education Association's research on "Competencies of Teaching Profession", TPACK is listed as one of the competencies a teacher must have for being qualified and quality teacher in Turkey $[38,39]$. Furthermore, a review of 2000 National Education Technology Standards developed by the International Society of Technology Standards in the USA confirms that technology-supported, effective learning environments were taken as basis and 2008 National Education Technology Standards were based on learning environment integrated with technology [40, 41].

The technology-supported, effective learning environment and learning environment integrated with technology suggest use of TPACK in teaching process. The technological practices used on the experiment group during the teaching process include practices supporting the technological pedagogical content knowledge. TPACK is the combination of content knowledge development and technological, teaching - learning knowledge development [4]. TPACK is the extension of pedagogical content knowledge. A teacher will have TPACK when that teacher knows how to teach subject area with technological tools and pedagogical strategies [42].

When it comes to a teacher's improvement in presentation of any subject area with the use of technology and knowledge of different pedagogical techniques, using technology in modern learning approaches for teaching a subject, TPACK does not make this harder or easier; it embodies information about using technology in solving problems encountered by the students and using technology to create new knowledge [43]. According to Mishra \& Koehler [37], TPACK is the basis of effective education to be performed with technology.

\section{Importance of Using Technology in Education}

In science and technology education, it is important for students to structure their knowledge with technology-supported activities enabling them to be active in the courses [44]. Technology based learning might be effective in improving students' involvement in courses, assuring students' progress as active learners, widening independency of students and improving social interaction of students [45]. It offers a number of conveniences such as visualization, vocalization and animation in the process of structuring information in the learner's mind [46]. Using technology in learning environments offers a wider range of learning conditions to students as well as inspiriting interest, putting students in the center and increasing motivation levels. From this point of view, use of technology in learning - teaching process has a key role [47].

Ardac \& Unal [48] argue that audiovisual presentation of information through education technologies is more effective for ensuring permanent learning. When explaining nature and natural events, science courses frequently use abstract notions like concept, principle and law; thus using educational software and explaining abstract concepts with visuals enrich the education [49]. The literature has studies highlighting the contributions of technology-supported teaching such as assuring effective participation of students in the learning - teaching process, improving success, developing positive attitude, increasing motivation, materializing abstract concepts, assuring active involvement of students in the courses, contributing to recollection and comprehension abilities, facilitating meaningful and long lasting learning, expanding the education-teaching environment and supporting constructivist learning $[3,5,7,36,46,47,50,51,52,53$, $54,55,56,57,58,59,60,61,62,63,64,65]$. Thus, 
teachers should take into consideration use of technology in planning learning - teaching process [66].

A review of the literature reveals that use of technology and technological practices in the learning-teaching process has some limitations. First of all, a classroom should have equipment sufficient for use of technology. Furthermore, it cannot be said that everyone has trouble-free internet access. Accessing and using technology are still problems of regions characterized with lower socioeconomic opportunities. It is not enough to incorporate technology into the education process. Because knowing what technology is and how it is used does not mean technology can be used in education. Contrary to other teaching materials, teachers should have specific knowledge and certain set of skills for preparing and using technological practices. Development of technology-based teaching design is not only a process related to having advanced level of technological knowledge; it also requires good level of content and pedagogical knowledge. Furthermore, the materials used for teaching should have properties enabling achievement of the student objectives specified on the curriculum. It is not easy to find educational software with features fit for the objectives and goals set on the curriculums $[67,68,69,70,71,72,73,74$, 75]. Koskela, Kiltti, Vilpola \& Tervonen [76] argued in his study that virtual learning environments should be designed based on student characteristics and needs since designs of poor quality reduce student motivation.

Accordingly, the disadvantages can be listed as insufficient technological equipment available in the schools, lack of technological practices with features fit for the goals in curriculums and cognitive levels of students as well as inadequate preparation of technological practices, which might contribute to the development of student competencies specified on the curriculum, and use of such practices by the teachers throughout the teaching process. In this context, it is considered that teachers should have TPACK competency for developing such practices and using them for teaching.

Furthermore, the education process must have qualities improving student attitudes [33]. As seen from a review of targeted skills to be developed by students in science education, attitude is one of the skills to be developed [34].

Accordingly, learning outcomes of students, such as success, can be developed through creating and working with learning - teaching processes and environments that will improve attitude towards the course in a positive way. Interactive and technologically enriched educations which can attract students' interest, expands the learning teaching process, assure direct, active and practical involvement of students in the learning process, and has a key role in realizing this objective.

Learning and teaching process must be enriched based on the idea that learning is as personal as a fingerprint and individuals have different ways of learning. Science teaching supported with technological practices includes technology-based practices that can enrich the learning teaching process.

Including technology supported, effective teaching environments and learning environment integrated with technology, which were underlined on 2000 and 2008 National Education Technology Standards developed by the International Society for Technology Standards [40, 41], in this study and use of TPACK, which is accepted as one of the teacher competencies on the Turkish Ministry of National Education's Draft National Teaching Strategy Statement [38] and Turkish Education Association's research on Competencies of Teaching Profession [39], in the learning and teaching process bring this study into prominence. Furthermore, the literature has studies arguing that technology should be used in the learning and teaching process $[6,52,56,60,66,77,78,79,80,81,82,83]$.

Based on the abovementioned reasons, it is agreed that studies aiming to determine impact of TPACK-supported teaching activities enriched with technological practices on the development of students' learning outcomes, such as attitude towards courses, will contribute to the literature. Accordingly, it is agreed that researches done for using technological practices in teaching are important and necessary for diversifying the learning - teaching process, improving levels of attitude towards the course, using TPACK as one of the teacher competencies and contributing to the literature.

\section{Purpose of Research}

This research was done for examining the effect of science teaching enriched with technological practices on attitudes of secondary school $7^{\text {th }}$ grade students towards science course. For this purpose, the research tried to answer the following questions.

1. Is there any significant difference between pre, post application and 3-month follow-up period attitudes of the $7^{\text {th }}$ grade students towards science course receiving technologically enriched science teaching?

2 . Is there any significant difference between pre, post application and 3-month follow-up period attitudes of the $7^{\text {th }}$ grade students towards science course receiving education based on the existing science course curriculum?

3 . Is there any significant difference between pre, post application and 3-month follow-up period attitudes of the $7^{\text {th }}$ grade students towards science course receiving technologically enriched science teaching and current science course curriculum?

\section{Materials and Methods}

\subsection{Research Design}

Quasi experimental method and pretest - experimental design with posttest control groups were used on the 
research [84]. Since randomness principle or drawing of lots were not used for selecting students for the control and experiment groups of the study and the existing classes were used, the research is quasi experimental [85].

\subsection{Research Workgroup}

The workgroup of the research was the $7^{\text {th }}$ grade students attending to a government secondary school in Ankara on the second semester of academic year 2015. Four classes were included in the research and random assignment method was used to determine which two classes would be experiment and which two would be control groups; two classes were appointed as the control group and the other two classes as the experiment group.

The workgroup of the research had total 74 students; 38 students in the control group and 36 students in the experiment group. The control group has 20 female and 18 male students and the experiment group had 18 female and 18 male students. The research's sampling method is a convenience sampling method because the execution stage of the research was conducted with a science teacher capable of teaching science course enriched with technological practices that can be easily monitored and directed by the researchers and with that teacher's students [85].

\subsection{Application of Research}

The 13-week research targeted the $7^{\text {th }}$ grade students attending to a government secondary school in Turkey in the academic year of 2015. Pretest, posttest and follow-up tests are not included in the execution period of this research. Necessary permissions were obtained before starting the research. The execution step of the research was performed by the same teacher during the science course of control and experiment groups. "Attitude towards Science Course Scale" was used a pretest at the beginning of the experiment for determining levels of attitude towards science course of the control and experiment group students. Force and Motion, Electricity in our Life, Light Units were provided 4 hours a week to the control and experiment groups and total 52 hours in 13-week period. The control group did not receive any experimental procedure, and a student centered education, based on science course curriculum existed in 2015 academic year, was offered.

The experiment group received education parallel to the education offered to the control group but it also included technologically enriched teaching practices. Practices supported with TPACK were used for technologically enriched science teaching offered to the experiment group. These technological applications are: "Smart Board, Tablet Computer, Student Answer Program, Online Exam Preparation and Application Programs, Online Puzzle Preparation and Application Program, Concept Mapping
Preparation Program, Concept Caricature Preparation Program, Digital Story Preparation Program, Virtual Classroom Applications, Informatics Network in Education, Vitamin, Morpa Campus, Okulistik and Learning Objects, Mobile Learning Activity with QR Code Applications, Web 2.0 Applications, Effective Presentation Preparation Tools, Simulation Preparation and Application Program, Animation Preparation and Application Program, Using Video in Education, Using Social Media Networks in Education etc.". The technological applications (learning-teaching activities and materials: online exam, online crossword, concept map, concept caricature, digital story, QR code, animation, presentation, simulation etc.) prepared in these programs were used in the experiment group so science teaching enriched with technological practices was realized. The control and experiment groups received student-centered education, designed based on the science course curriculum and activities given on the course book, at the execution phase of the research. There was no other impact that could change the students' attitudes towards the course. In addition to these, the experiment group had concept cartoons; animation and concept map prepared using online programs at the introduction step of the courses as well as simulation experiments at the development step; presentations and videos at the explanation step and augmented reality applications, digital stories at the expansion step and puzzles, exams, concept maps on the assessment step. QR Code and virtual class applications were also included on each step of the course. These activities were prepared using online programs and presented on the teaching process with aids such as smart board and tablets.

When the experiment procedure was completed, the "Attitude towards Science Course Scale" was applied as posttest to the students in the control and experiment groups. The "Attitude towards Science Course Scale" was applied to the students in the experiment group 3 months after the posttest, as follow up test.

\subsection{Data Collection Tools}

This research used the "Attitude towards Science Course Scale" designed by Tepe [86] for determining the attitude towards science course level of students. This scale of 40 items was designed based on the 5-point Likert assessment structure from "Strongly Agree" to "Strongly Disagree" and with reliability of 0.82 . Before the application step of this research, the scale was applied on 218 seventh grade students attending to the same secondary school as well as control and experiment groups. As a result of analyzing collected data, the Cronbach Alpha reliability coefficient of this scale was calculated as 0.85 for this research. This coefficient confirms that the scale is reliable.

When analyzing the data collected by applying this scale, "Strongly Agree" answer given for each positive statement on the items was graded 5 points; "Agree" 4 points, 
"Somewhat agree" 3 points, "Disagree" 2 points and "Strongly Disagree" 1 point. The abovementioned grading was reversed for scoring the negative statements on the items. The total point obtained from the scale was divided by the number of items on the scale and attitude score of each student was calculated. Accordingly, the minimum score to be received from this is 1 and the maximum score is 5 . The scale was used as the pretest for determining the attitude towards science course levels of the $7^{\text {th }}$ grade students at the beginning of the research and as the posttest for determining effect of the experimental procedure at the end of research and as the follow-up test 3-month after completing the research. Total score obtained from the test shows the attitude level of an individual.

\subsection{Data Analysis}

Microsoft Excel 2010 electronic table program and SPSS 22 statistical analysis program were used to analyze quantitative data of the research. Descriptive statistical techniques were used for determining general distribution of answers given by the students on the scale and examining whether quantitative data shows the normal distribution. Furthermore, central tendency (mean, mode and median) and central distribution (standard deviation, skewness and kurtosis) values of the scale scores were used. "Independent Sample t-test" analysis was used to determine whether there is significant level of difference between scores of the control and experiment groups in the research. "One-Way ANOVA for Repeated Measures" was used to determine whether there is significant level of different between point averages calculated within the control and experiment groups with pretest at the beginning of research period, posttest at the end of research and follow-up test done three months after completing the research. The Bonferroni test was applied to determine the direction of the meaningful difference at ANOVA. All analyzes were evaluated to have significance level of .05 [87].

If analyzes concluded that there is a statistically significant difference between the groups, effect size was calculated to determine whether this difference is significant in practice. When determining the effect size, Cohen's $d$ was calculated in the t-test analysis for independent groups and Eta Squared value was calculated in the "One-Way ANOVA for Repeated Measures". If d value is less than .20 according to Cohen [88], the effect is small; if the value is .50 or over .80 , the effect is medium and large, respectively and if the Eta Squared value is $.01, .06$ and .14 , the effect size can be interpreted as small, medium and large, respectively.

\section{Findings}

Before statistically analyzing pretest, posttest and follow-up test attitude towards science course scores of the students in the control and experiment groups, the statistical method to be used for analyzing quantitative data obtained from the scale was researched and decided. In quantitative researches, both parametric and non-parametric statistical methods can be used for data analysis. For using parametric statistical analysis methods, the quantitative data obtained from the tests and scales used on the research process must have normal distribution [89].

Accordingly, analyzes were done to determine the statistical method to be used for analyzing data obtained from the attitude towards science course scale and the results are given on the Table 1. Based on these findings, the research examined whether the pre, post and follow up test scores of the students in the control and experiment groups have normal distribution.

As seen on Table 1, point average of control group students calculated from attitude pretest as well as median and mode values are close to each other. Also, point average of experiment group students calculated from the pretest as well as median and mode values are close to each other. In a similar manner, point average, median and mode values of the control group in the posttest and point average, median and mode values of the experiment group in the posttest are close to each other. Furthermore, follow-up test score average, median and mode values of the control group are close to each other whereas the follow-up test scores average, median values of the experiment group are close to each other. Besides, it is seen that kurtosis and skewness values of the pretest, posttest and follow-up test points scored by the control and experiment group students are within the range of -1.5 and +1.5 .

Table 1. Descriptive Statistical Results Related to Attitude Pretest, Posttest and Follow-Up Test of Students in Control and Experiment Groups

\begin{tabular}{|cccccccccc|}
\hline Test & Group & $\mathbf{N}$ & $\overline{\mathbf{X}}$ & $\mathbf{S}$ & Median & Mod & Skewness & Kurtosis \\
\hline \multirow{2}{*}{ Pretest } & Control & 38 & 137,66 & 17,43 & 140,00 & 140 & $-0,44$ & $-0,40$ \\
& Experiment & 36 & 136,28 & 19,74 & 136,50 & 134 & $-0,39$ & $-0,66$ \\
\hline \multirow{2}{*}{ Posttest } & Control & 38 & 138,76 & 17,86 & 140,50 & 137 & $-0,45$ & $-0,15$ \\
& Experiment & 36 & 157,39 & 20,82 & 159,00 & 159 & $-0,45$ & $-0,13$ \\
\hline \multirow{2}{*}{ Follow-up } & Control & 38 & 139,26 & 19,35 & 141,50 & 137 & $-0,35$ & $-0,20$ \\
Test & Experiment & 36 & 154,89 & 20,85 & 157,50 & 154 & $-0,54$ & $-0,39$ \\
\hline
\end{tabular}


The fact that the control and experiment groups' students have arithmetic average, median and mode values close to each other in terms of pre, post and follow up attitude tests as well as the kurtosis and skewness values' range (between -1.5 and +1.5 ) of pre, post and follow up test scores and the findings confirming that the number of sampling in both control and experiment groups is higher than 30 show that data obtained from pre, post and follow up attitude tests applied to the control and experiment groups have normal distribution [90, 91].

It was decided to use parametric tests for analyzing data confirmed to have normal distribution based on the descriptive statistical results. Accordingly, "Independent Sample t-test" was used to determine whether there is significant difference between pre, post and follow up attitude test score averages of the control and experiment groups. "One-Way ANOVA for Repeated Measures" was used to analyze whether there is a significant level of difference between pre, post and follow up attitude test average points within the control and experiment groups, separately.

Attitude pretest scores were compared statistically for determining whether attitude levels of students in the control and experiment groups were equal at the beginning of the experimental procedure and the results are given on Table 2. Total score of the attitude scale was divided by the number of items on the scale to calculate the attitude score for each student.

Table 2. t-Test Results Related to Attitude Pretest Scores of The Independent Groups

\begin{tabular}{|ccccccc|}
\hline Group & $\mathbf{N}$ & $\overline{\mathbf{X}}$ & $\mathbf{S}$ & $\mathbf{d f}$ & $\mathbf{t}$ & $\mathbf{p}$ \\
\hline Control & 38 & 3,44 & 0,44 & 72 & 0,32 & 0,75 \\
Experiment & 36 & 3,41 & 0,49 & & & \\
\hline
\end{tabular}

As seen on Table 2 , the students of the control $(\bar{X}=3.44)$ and experiment $(\bar{X}=3.41)$ groups did not have a significant level of difference in terms of attitude pretest scores at the beginning of the research $\left(t_{(72)}=0,32 ; p>, 05\right)$. This finding suggests that the students in the control and experiment groups had similar levels of attitude at the beginning of the research.

Table 3. t-Test Results Related to Attitude Posttest Scores of The Independent Groups

\begin{tabular}{|ccccccc|}
\hline Group & $\mathbf{N}$ & $\overline{\mathbf{X}}$ & $\mathbf{S}$ & $\mathbf{d f}$ & $\mathbf{t}$ & $\mathbf{p}^{*}$ \\
\hline Control & 38 & 3,46 & 0,45 & & & \\
Experiment & 36 & 3,94 & 0,52 & & $-4,14$ &, 00 \\
\hline
\end{tabular}

$* \mathrm{p}<0.05$

As seen from the findings on the Table 3 , there is a significant level of difference between attitude posttest scores of the control and experiment group students at the end of the research $\left(\mathrm{t}_{(72)}=-4,14 ; \mathrm{p}<, 05\right)$. A review of arithmetic means related to attitude of the control $(\bar{X}=3.46)$ and experiment $(\bar{X}=3.94)$ groups would confirm that scores of the experiment group students are significantly higher than the scores of the control group students. The effect size value of this difference was calculated as Cohen's d $=.99$. This value can be interpreted as a high level effect [88].

Table 4. t-Test Results Related to The Attitude Follow-up Test Scores of The Independent Groups

\begin{tabular}{|ccccccc|}
\hline Group & $\mathbf{N}$ & $\overline{\mathbf{X}}$ & $\mathbf{S}$ & $\mathbf{d f}$ & $\mathbf{t}$ & $\mathbf{p}^{*}$ \\
\hline Control & 38 & 3,48 & 0,48 & & & \\
Experiment & 36 & 3,87 & 0,52 & & $-3,34$ &, 00 \\
\hline
\end{tabular}

$* \mathrm{p}<0.05$

As seen from the findings on the Table 4, there is a significant level of difference between attitude scores of the control $(\bar{X}=3.48)$ and experiment $(\bar{X}=3.87)$ group students on the third month following completion of the research and this difference is in favor of the experiment group $\left(t_{(72)}=-3,34 ; p<, 05\right)$. In other words, attitude scores of the experiment group students were significantly higher than the control group students at the end of three-month period following the completion of research application phase. The effect size value of this difference was calculated as Cohen's $d=.78$. This value can be interpreted as a medium level effect [88].

Table 5. Central Tendency and Spreading Measurements Related to Attitude Pretest, Posttest and Follow-up Test Scores of the Control Group Students

\begin{tabular}{|ccccc|}
\hline $\begin{array}{c}\text { Measurement } \\
\text { No }\end{array}$ & Measurement & N & $\overline{\mathbf{X}}$ & $\mathbf{S}$ \\
\hline $\mathbf{1}$ & Pretest & 38 & 3,44 & 0,44 \\
$\mathbf{2}$ & Posttest & 38 & 3,46 & 0,45 \\
$\mathbf{3}$ & Follow up Test & 38 & 3,48 & 0,48 \\
\hline
\end{tabular}

Table 6. One-Way ANOVA Results for Repeated Measures Related to Attitude Pretest, Posttest and Follow up Test Scores of The Control Group Students

\begin{tabular}{|ccccccc|}
\hline $\begin{array}{c}\text { Source of } \\
\text { Variance }\end{array}$ & $\begin{array}{c}\text { Sum of } \\
\text { Square }\end{array}$ & df & $\begin{array}{c}\text { Mean } \\
\text { Square }\end{array}$ & F & p & $\begin{array}{c}\text { Significant } \\
\text { Difference }\end{array}$ \\
\hline $\begin{array}{c}\text { Between } \\
\text { Subjects }\end{array}$ & 17,14 & 37 & 0,463 & & & \\
Measurement & $\mathbf{0 , 0 3 2}$ & $\mathbf{2}$ & $\mathbf{0 , 0 1 6}$ & 0,20 &, 82 & - \\
Error & 5,91 & 74 & 0,079 & & & \\
Total & 23,082 & 113 & & & & \\
\hline
\end{tabular}

As seen on the Table 5, the attitude follow-up test average points $(\bar{X}=3.48)$ of the control group students are higher than the average of posttest $(\bar{X}=3.46)$ and pretest $(\bar{X}=3.44)$ scores. However, as suggested by the findings on the Table 6 , there is no significant level of difference between the pretest, posttest and follow up test scores (Wilks' Lambda $=0,99, \mathrm{~F}_{(2-74)}=0,20 ; \mathrm{p}>, 05$ ). Accordingly, it might be concluded that the control group students have similar levels of attitude at the beginning and end of the research and at the third month following the completion of application step. 
Table 7. Central Tendency and Spreading Measurements Related to Attitude Pretest, Posttest and Follow up Test Scores of The Experiment Group Students

\begin{tabular}{|ccccc|}
\hline $\begin{array}{c}\text { Measurement } \\
\text { No }\end{array}$ & Measurement & N & $\overline{\mathbf{X}}$ & $\mathbf{S}$ \\
\hline $\mathbf{1}$ & Pretest & 36 & 3,41 & 0,49 \\
$\mathbf{2}$ & Posttest & 36 & 3,94 & 0,52 \\
$\mathbf{3}$ & Follow up Test & 36 & 3,87 & 0,52 \\
\hline
\end{tabular}

Table 8. One-Way ANOVA Results for Repeated Measures Related to Attitude Pretest, Posttest and Follow up Test Scores of The Experiment Group Students

\begin{tabular}{|ccccccc|}
\hline $\begin{array}{c}\text { Source of } \\
\text { Variance }\end{array}$ & $\begin{array}{c}\text { Sum of } \\
\text { Square }\end{array}$ & df & $\begin{array}{c}\text { Mean } \\
\text { Square }\end{array}$ & $\mathbf{F}$ & $\mathbf{p}^{*}$ & $\begin{array}{c}\text { Significant } \\
\text { Difference }\end{array}$ \\
\hline $\begin{array}{c}\text { Between } \\
\text { Subjects }\end{array}$ & 23,034 & 35 & 0,658 & & & \\
Measurement & $\mathbf{5 , 9 8 7}$ & $\mathbf{2}$ & $\mathbf{2 , 9 9 4}$ & 46,77 &, 00 & $1-2$ \\
Error & 4,480 & 70 & 0,064 & & & $1-3$ \\
Total & 33,501 & 107 & & & & \\
\hline
\end{tabular}

$* \mathrm{p}<0.05$

According to Tables 7 and 8 , there is a significant level of difference between attitude pretest $(\bar{X}=3.41)$, posttest $(\bar{X}=3.94)$ and follow up test $(\bar{X}=3.87)$ scores of the experiment group students (Wilks' Lambda $=0,04, \mathrm{~F}_{(2-70)}=$ $46,77 ; \mathrm{p}<, 05)$. The Bonferroni test was applied to determine the difference between the measurements. According to the Bonferroni test results at the Table 8, this significant difference is in favor of the posttest when the pretest and posttest average points are compared and in favor of the follow-up test when the follow-up test average point and pretest average point are compared.

This finding suggests that the attitude levels of the experiment group students at the end of research and on the third month following the completion of research are at a level significantly higher than the level at the beginning of the research. Besides, the attitude point average on the third month following the completion of experimental procedure (follow up test) is less than the posttest point average but, as seen on the Table 8 , there is no significant difference between the follow up test point average and posttest point average. In other words, it might be argued that attitude levels of the experiment group students are similar at the end of the research and on the third month following the completion of the research. The effect size value was calculated as Eta Squared $=0.97$. This level suggests a high level of effect. Accordingly, it might be argued that technologically enriched science teaching has high level effect on development of attitude [88].

\section{Discussion and Conclusions}

\subsection{Discussion}

This research was done for the purpose of studying the effect of science teaching enriched with technological practices on the attitude levels of the $7^{\text {th }}$ grade students. The control and experiment group students were at a similar position at the beginning of the research, in terms of attitude levels $\left(\mathrm{t}_{(72)}=0,32 ; \mathrm{p}>, 05\right)$. This result is fit for the purpose of comparing the effect of experimental procedure on the attitude levels of students in the control and experiment groups. It is confirmed that the attitude scores of the experiment group students were significantly higher than the students in the control group at the end of the research $\left(\mathrm{t}_{(72)}=-4,14 ; \mathrm{p}<, 05\right)$. The attitude scores of the experiment group students on the third month following the completion of research were significantly higher when compared to the students in the control group $\left(\mathrm{t}_{(72)}=-3,34\right.$; $\mathrm{p}<, 05$ ). Accordingly, it might be argued that science teaching enriched with the technological practices is more effective in increasing attitude levels of the $7^{\text {th }}$ grade students and assuring preservation of attitudes developed for the science teaching at the end of three-month period when compared to the teaching offered to the control group.

The students in the control group had similar levels of attitude at the beginning and end of the research and on the third month following the research $\left(\mathrm{F}_{(2-74)}=0,20 ; \mathrm{p}>, 05\right)$.

The attitude scores of the students in the experiment group at the end of the research and on the third month following the completion of research were significantly higher than the scores at the beginning of the research $\left(\mathrm{F}_{(2-70)}=46,77 ; \mathrm{p}<, 05\right)$. Furthermore, the attitude levels of the experiment group were similar at the end of research and on the third month following the completion of research. Based on these findings, it might be argued that science teaching enriched with technological practices is effective in improving attitude levels of the students and this improvement of attitude level continued at the end of three-month period. The reason of changing attitudes towards science is the students who are active in the course of interactive education [92].

A review of the literature about teaching enriched with technological practices confirmed that a study by Benli Kayabasi \& Sarikaya [30] concluded that technology-supported education has significant effect on the attitudes developed by the $7^{\text {th }}$ grade students towards science. A research by Kara \& Yesilyurt [93] concluded that Vitamin, the educational software designed in the format of course software, has positive effect on the attitude towards biology. A research by Ogreten \& Ulucinar Sagir [94] determined that an interactive teaching method significantly contributes to the improvement of students' attitude towards science courses. Kumas [95] concluded that technology-supported teacher guiding materials increase motivation of the $9^{\text {th }}$ grade students and improve their success by intriguing them. A study by Pekmezci [96] determined that short stories supported with information technologies significantly increase attitude levels of the $6^{\text {th }}$ grade students towards science course. Another study by Guler [97] concluded that use of interactive, 3-dimensional technologies in 
education assures students who are more attentive to the lesson, more active and curios about the lesson and ensures development of positive attitude towards the course. A study Demirer [98] concluded that computer-based and web-based digital narration activities offered at the $6^{\text {th }}$ grade primary school contribute to development of student attitudes towards the course. A research by Sakiz, Ozden, Aksu \& Simsek [99] revealed that use of smart board during science lessons increases the $4^{\text {th }}$ grade students' attitudes towards science lessons.

Furthermore, the studies included in the literature and conducted by Chen \& Howard [100], Dagdalan \& Tas [79], Ertepinar, Demircioglu, Geban \& Yavuz [101], Kara \& Yesilyurt [93], Kirbag Zengin, Kirilmazkaya \& Kececi [102], Frailich, Kesner \& Hofstein [103], Jose \& Wiliamson [104], Ozmen [58], Selwyn [105], Stokes [106], Tekinarslan et al. [60], Winer \& Cooperstook [107] support the conclusion of this research.

The studies show that technological materials used for education, such as smart boards, simulations, virtual manipulatives and dynamic software programs support learning and teaching activities [55, 60, 99, 108].

Based on the fact that computer-supported teaching is also a form of technology-supported teaching, the literature reviewing effect of technology-supported teaching and computer-supported teaching on the attitude towards the course is included. For example, a study by Akcay, Tuysuz \& Feyzioglu [92] confirmed that computer-supported and student centered learning methods as well as computer-supported and teacher centered method assure positive improvement in students' achievement in science course, attitudes towards the science course, attitudes towards the science teacher and attitudes towards computer when compared to the conventional learning methods. Furthermore, it is determined that this positive change was much more evident on the experiment group receiving student centered education. The literature confirms that computer supported science education has significant level of effect on the development of attitude towards science education $[109,110,111,112,113]$, attitude towards computer [109, 113], and attitude towards science teacher [112]. Aycan et al. [114] tried teaching "Motion on Earth" unit on computer environment. As a result of that research, it is concluded that students considered "Motion on Earth" subject as very interesting and easy to remember when taught on the computer environment. Arslan [115] concluded that computer supported education has positive effect on the students' attitude towards course. As seen on the abovementioned researches, technology supported and computer supported teaching has positive effect on development of attitude towards the course. If we bear in mind that computer supported teaching is a form of technology-supported teaching, the abovementioned research results support the conclusion of this research; education supported with technological practices significantly improves the level of attitude.
However, a study by Curaoglu [116] concluded that technologically enriched education has no significant effect on development of the $6^{\text {th }}$ grade students' attitude towards math course. Oner [117] and Yemen [62] respectively did studies with the $7^{\text {th }}$ grade and $8^{\text {th }}$ grade students and concluded that technology-supported education increases level of success in math courses but has no significant effect on the attitude towards math course. Studies by Cepni, Tas \& Kose [118], Guven \& Sulun [52] and Kahraman [119] stated that computer-supported education has no significant effect on development of attitude towards the course. This conclusion does not support the conclusion of this research, which argues that teaching enriched with technological practices significantly contributes to the development of attitude level. If we bear in mind that the abovementioned research periods are as short as 3 to 4 weeks, it might be argued that the conclusions of those researches are related to lack of long term application periods, needed for development of affective characteristics such as attitude.

\subsection{Conclusions}

In conclusion, it is concluded that science teaching enriched with technological practices has a significant level of contribution to the attitude towards science course development of secondary school the $7^{\text {th }}$ grade students and this improvement was sustained for a period of three months after completing the research. However, it is determined that the attitude towards science course levels of students in the control group has not changed on a significant level.

Furthermore, the attitude towards science course levels of the control and experiment group students were similar at the beginning of the research but the attitudes of students in the experiment group towards science course were significantly higher than the students in the control group at the end of research and on the third month following completion of the research. These results show that science teaching enriched with technological practices is significantly effective on the development of student attitudes towards science course and preservation of this development, and teaching methods used on the control group are not that effective. Root cause of this conclusion is the fact that technological practices interact with the students; this intrigues students, diversifies the learning teaching process and assures direct, active and practical participation of students in the learning process.

Accordingly, it might be argued that use of technological practices in the process of science teaching can contribute to the effective learning product and results. If we bear in mind the fact that science teaching enriched with technological practices significantly improves the attitude towards science course levels, it is agreed that learning teaching process should include technological practices.

It is agreed that teachers should have TPACK, which is 
one of the teacher training competencies, for incorporating technological practices into learning - teaching process. Accordingly, it might be argued that TPACK teaching should be included in the teacher training process. For that purpose, it is agreed that TPACK and Technological Practices courses should be added to curriculums followed at Faculties of Education.

\section{Acknowledgements}

We are very grateful to experts for their appropriate and constructive suggestions to improve this template.

\section{REFERENCES}

[1] A. Efendioglu, T. Yanpar Yelken. TPAB Temelli Fen ve Teknoloji Dersi icin Coklu Ortam Benzetimi Gelistirme ve Ogretim Surecinde Kullanma, T. Yanpar Yelken, H. Sancar Tokmak, S. Ozgelen \& L. Incikabi (Ed.), Fen ve Matematik Egitiminde Teknolojik Pedagojik Alan Bilgisi Temelli Ogretim Tasarimlari (pp.81-104), Ankara, Ani Yayincilik, 2013.

[2] E. Ekici, F. Taskin Ekici, I. Kara. Validity and Reliability Study of ICT Self-Efficacy Perception Scale for Teachers, Pamukkale University Journal of Education, Vol.31, 53-65, 2012.

[3] S. Caglar. Technology Assisted Instruction of Titrations Subject in University, Unpublished Master Thesis, Balikesir Universitesi Fen Bilimleri Enstitusu, Balikesir, 2007.

[4] M. L. Niess. Preparing Teachers to Teach Science and Mathematics with Technology: Developing a Technology Pedagogical Content Knowledge, Teaching and Teacher Education, Vol.21, No.5, 509-523, 2005.

[5] Y. Selim, E. Tatar, R. Oz. An Investigation of Instructional Materials Prepared by Mathematics Preservice Teachers on TPCK Model, Erzincan University Journal of Science and Technology, Vol.2, No.2, 239-251, 2009.

[6] B. Timur. The Development of Pre-Service Science Teachers' Technological Pedagogical Content Knowledge in Force and Movement Subjects, Unpublished Doctoral Dissertation, Gazi Universitesi Egitim Bilimleri Enstitusu, Ankara, 2011.

[7] M. Dogan. Prospective Turkish Primary Teachers' Views about the Use of Computers in Mathematics Education, Journal of Mathematics Teacher Education, Vol.15, No.4, 329-341, 2012.

[8] S. Sani Bozkurt. Ozel Egitimde Dijital Destek: Yardimci Teknolojiler, Acikogretim Uygulamalari ve Arastirmalari Dergisi, Vol.3, No.2, 37-60, 2017.

[9] C. Akyol, A. Dikici. The Effect of Poetical Teaching Technique on Academic Achievement and Attitude of the Students, Elementary Education Online, Vol.8, No.1, 48-56, 2009.
[10] C. Guden, B. Timur. Examining Secondary School Students' Attitudes Towards Science Based on Various Variables (Canakkale Sample), International Journal of Active Learning, Vol.1, No.1, 49-72, 2016.

[11] S. Gurbuzoglu Yalmanci. The Validity and Reliability of Biology Attitude Scale, PAU Journal of Education, Vol.40, 248-262, 2016.

[12] N. Karasakaloglu, A.S. Saracaloglu. The Relationship between Academic Self-Concept Along With Achievement, Attitudes toward Turkish Lesson of Prospective Elementary School Teachers, Yuzuncu Yil Universitesi Egitim Fakultesi Dergisi, Vol.6, No.1, 343 - 363, 2009.

[13] I. Kenar, M. Balci. The Development of Attitudes toward Science and Technology Lesson Scale: The Case of $4^{\text {th }}$ and $5^{\text {th }}$ Grade Primary School Students, Dumlupinar University Journal of Social Science, No.34, 201-210, 2012.

[14] N. I. Kurbanoglu, M. Takunyaci. An Investigation of the Attitudes, Anxieties And Self-Efficacy Beliefs towards Mathematics Lessons High School Students' in Terms of Gender, Types of School, and Students' Grades, Uluslararasi Insan Bilimleri Dergisi, Vol.9, No.1, 110-130, 2012.

[15] S. Ozbas. High School Students' Attitudes toward Biology Course, Turkish Studies, Vol.11, No.9, 659-668, 2016.

[16] A. Adiguzel. The Investigation of Different Variables of the Relationship between Teachers Candidates' Attitudes for Learning and Information Literacy Skills, International Journal of Curriculum and Instructional Studies, Vol.4, No.7, 13-24, 2014.

[17] S. K. Abell, N. G. Lederman. Handbook of Research on Science Education, Lawrence Erlbaum Associates, New Jersey, 2007.

[18] R. A. George. Cross-Domain Analysis of Change in Students' Attitudes toward Science and Attitudes about the Utility of Science, International Journal of Science Education, Vol.28, No.6, 571-589, 2006.

[19] N. Mattern, C. Schau. Gender Difference in Attitude Achievement Relationships over Time among White Middle School Students, Journal of Research in Science Teaching, Vol.39, No.4, 324-340, 2002.

[20] H. Altinok. The Attitudes of Fifth Graders towards the Science Course in Terms of Gender and Achievement, Eurasian Journal of Educational Research, No.17, 81-91, 2004.

[21] A. P. Dieck. An Effect of a Newsletter on Children's Interest in An Attitude toward Science, Unpublished Master's Thesis, Tempe, Arizona State University, 1997.

[22] A. Martinez. Student Achievement in Science: A Longitudinal Look at Individual and School Differences, Unpublished Doctoral Thesis, Boston, Harvard University, 2002.

[23] S. Yaman, F. Oner. Ilkogretim Ogrencilerinin Fen Bilgisi Dersine Bakis Acilarini Belirlemeye Yonelik Bir Arastirma, Kastamonu Egitim Dergisi, Vol.14, No.1, 339-346, 2006.

[24] H.I. Yildirim, F. Kansiz. Investigation of Secondary School Students' Attitudes towards Science Course According to 
Some Variables - 2, Turkish Studies International Periodical for the Languages, Literature and History of Turkish or Turkic, Vol.12, No.25, 779-806, 2017.

[25] Y. R. Simon. Pursuit of Happiness and Lust for Power in Technological Society, Philosophy and Technology. Free Press, New York, 1983.

[26] M. McCannon, T. B. Crews. Assessing the Technology Needs of Elementary School Teachers, Journal of Technology and Teacher Education, Vol.8, No.2, 111-121, 2000.

[27] V. Komis, M. Ergazakia, V. Zogzaa. Comparing Computer-Supported Dynamic Modeling and "Paper \& Pencil" Concept Mapping Technique in Students' Collaborative Activity, Computers \& Education, Vol.49, No.4, 991-1017, 2007.

[28] D. Jonassen, T. Reeves. Learning with Technology: Using Computers as Cognitive Tools, In D. 1-I. Jonassen (Ed.), Handbook of Research on Educational Communications and Technology, 693-719, 1996.

[29] B. Means. Using Technology to Advance Educational Goals, In B. Means (Ed.), Technology and Education Reform: The Reality behind the Promise, 1-22, San Fransisco, Jossey-Bass Publishers, 1994.

[30] E. Benli, Y. Kayabasi, M. Sarikaya. The Effect of Supported Science Education to the Science Achievement, the Permanence of Knowledge and the Attitudes toward Science of $7^{\text {th }}$ Grade Students, Gazi University Journal of Gazi Educational Faculty, Vol.32, No.3, 733-760, 2012.

[31] H. Rugayah, H. Hashim, N. M. Wan. Attitudes toward Learning about and Working with Computers of Students at Unit, The Turkish Online Journal of Educational Technology (TOJET), Vol.3, No.2, 24-35, 2004.

[32] S. Cengizhan. The Effects of Computer-Assisted and Project-Based Instructional Designs on Student' Academic Achievement and Learning Retention in Terms of Independent and Collaborative Learning Styles, Unpublished Doctoral Dissertation, Yildiz Teknik Universitesi Sosyal Bilimler Enstitusu, Istanbul, 2006.

[33] Milli Egitim Bakanligi (MEB). Ilkogretim Fen ve Teknoloji Dersi $(6,7$ ve 8 . siniflar) Ogretim Programi, Online available from http://ttkb.meb.gov.tr/program2.aspx?islem=1\&kno=25, 2006.

[34] Milli Egitim Bakanligi (MEB). Ilkogretim Kurumlari Fen Bilimleri Dersi (3, 4, 5, 6, 7 ve 8. Siniflar) Ogretim Programi, Online available from http://ttkb.meb.gov.tr/www/guncellenen-ogretim-programl ari/icerik/151, 2013.

[35] H. Yildiz. Analysis of Development of Technological Pedagogical Content Knowledge on Geometry of Mathematics Teachers, Unpublished Doctoral Dissertation, Karadeniz Teknik Universitesi Egitim Bilimleri Enstitusu, Trabzon, 2017.

[36] D. Akyuz. TPACK Analysis of Preservice Teachers under Different Instruction Methods and Class Levels, Turkish Journal of Computer and Mathematics Education, Vol.7, No.1, 89-111, 2016.

[37] P. Mishra, M. Koehler. Technological Pedagogical Content
Knowledge: A Framework for Teacher Knowledge, The Teachers College Record, Vol.108, No.6, 1017-1054, 2006.

[38] Milli Egitim Bakanligi (MEB). Ulusal Ogretmenlik Stratejisi Belgesi Taslagi, Online available from kesan.meb.gov.tr/mebgiysgdosyalar/2012g06/19115157gul usalogr.docx, 2011.

[39] Turk Egitim Dernegi (TED). Ogretmen Yeterlikleri, Online available from http://portal.ted.org.tr/yayinlar/OgretmengYeterlikgKitap.p df, 2009.

[40] International Society for Technology in Education (ISTE) ISTE National Educational Technology Standards (NETS) and Performance Indicators for Teachers. Online available from http://www.iste.org 2000.

[41] International Society for Technology in Education (ISTE). Advancing Digital Age Teaching. Online available from https://www.iste.org, 2008.

[42] S. J. Jang, K. C. Chen. From PCK to TPACK: Developing a Transformative Model for Pre-Service Science Teachers, Journal of Science Education and Technology, Vol.19, No.6, 553-564, 2010.

[43] M. J. Koehler, P. Mishra. Introducing Technological Pedagogical Knowledge. In AACTE (Eds.), The Handbook of Technological Pedagogical Content Knowledge for Educators (p.3-30), New York, Routledge, 2008.

[44] A. G. Balim, G. Aydin, S. Turkoguz, E. Evrekli, D. Inel. Technologically Supported Mind Map Applications for Science and Technology Teachers, Bati Anadolu Egitim Bilimleri Dergisi (BAED), Vol.2, No.4, 91-100, 2011.

[45] R. Jowallah. Using Technology Supported Learning to Develop Active Learning in Higher Education, US-China Education Review, Vol.5, No.12, 42-46, 2008.

[46] Y. Ersoy. Movements for Innovations of Mathematics Education-I: Technology Supported Mathematics Teaching, The Turkish Online Journal of Educational Technology, Vol.4, No.2, 51-63, 2005.

[47] O. Karamustafaoglu, M. Aydin, H. Ozmen. Bilgisayar Destekli Fizik Etkinliklerinin Ogrenci Kazanimlarina Etkisi: Basit Harmonik Hareket Ornegi, TOJET, Vol.4, No.4, Makale: 10, 2005.

[48] D. Ardac, S. Unal. Does The Amount Of On-Screen Text Influence Student Learning From A Multimedia-Based Instructional Unit? Instructional Science, Vol.36, No.1, 75-88, 2008.

[49] N. Yigit. Bilim, Fen, Teknoloji ve Egitim Programlarina Yansimalari. S. Cepni (Ed.). Kuramdan Uygulamaya Fen ve Teknoloji Ogretimi (pp. 275-299), Ankara, Pegem A Yayincilik, 2005.

[50] E. Akgun, E. O. Yilmaz, S. S. Seferoglu. Vizyon 2023 Strateji Belgesi ve Firsatlari Artirma ve Teknolojiyi Iyilestirme Hareketi (FATIH) Projesi: Karsilastirmali Bir Inceleme, XIII. Akademik Bilisim Konferansi Bildirileri, Malatya: Inonu Universitesi, 115-122, 2011.

[51] P. Dilworth, A. Donaldson, M. George, D. Knezek, M. Searson, K. Starkweather, M. Strutchens, J. Tillotson, S. Robinson. Preparing Teachers for Tomorrow's Technologies, TechTrends, Vol.56, No.4, 11-14, 2012. 
[52] G. Guven, Y. Sulun. Bilgisayar Destekli Ogretimin 8.Sinif Fen ve Teknoloji Dersindeki Akademik Basariya ve Ogrencilerin Derse Karsi Tutumlarina Etkisi, Turk Fen Egitimi Dergisi, Vol.9, No.1, 68-79, 2012.

[53] B. Ince. Determining Mathematics Teachers' Difficulties in Technology Integration to Teaching Process in the Frame of Technological Pedagogical Content Knowledge (TPCAK), Unpublished Master Thesis, Dokuz Eylul Universitesi Egitim Bilimleri Enstitusu, Izmir, 2015.

[54] H. Kaya, F. Aydin. Students' Views towards Interactive White Board Applications in The Teaching of Geography Themes in Social Knowledge Lessons, Journal of World of Turks [Zeitschrift fur die Welt der Turken] Vol.3, No.1, Online available from http://www.dieweltdertuerken.org/index.php/ZfWT/article/ view/188/kaya-aydin, 2011.

[55] Z. Kirbag Zengin, G. Kirilmazkaya, G. Kececi. The Effect of Computer Assisted Instruction in Science and Technology Course to Teachers and Students' Attitudes and Achievements, The Journal of Academic Social Science Studies, Vol.30, 453-466, 2014.

[56] A. T. Korucu, A. Yucel. Information Technologies Teachers' Ideas about Dynamic Web Technologies Use in Education, Educational Technology Theory and Practice, Vol.5, No.2, 126-152, 2015.

[57] D. Laney. Micro Computers and Social Studies, OCSS Rewiev, Vol.26, 30-37, 1990.

[58] H. Ozmen. Fen Ogretiminde Ogrenme Teorileri ve Teknoloji Destekli Yapilandirmaci (Constructivist) Ogrenme, The Turkish Online Journal of Educational Technology, Vol.3, No.1, 100-111, 2004.

[59] E. Tatar, A. Akkaya, T. B. Kagizmanli. The Views of Primary School Mathematics Teachers on the Applicability of GeoGebra Software in Courses, Turkish Journal of Computer and Mathematics Education (TURCOMAT), Vol.2, No.3, 181-197, 2011.

[60] E. Tekinarslan, E. Top, M. D. Gurer, A. Yikmis, M. Ayyildiz, A. Karabulut, O. Savas. Effect of Teaching With Smart Whiteboard by Using Multimedia Objects on the Attitudes of Teacher Candidates toward Teaching with Enriched Content, Educational Technology Theory and Practice, Vol.5, No.2, 22-38, 2015.

[61] B. S. Woodard. Technology and the Constructivist Learning Environment: Implications for Teaching Information Literacy Skills, Research Strategies, Vol.19, No.3-4, 181-192, 2003.

[62] S. Yemen. The Effect of Technology Assisted Instruction on $8^{\text {th }}$ Grade Students? Achievement and Attitudes on Analytical Geometry Instruction, Unpublished Master Thesis, Dokuz Eylul Universitesi Egitim Bilimleri Enstitusu, İzmir, 2009.

[63] B. Hug, J. Krajcik, R. W. Marx. Using Innovative Learning Technologies to Promote Learning and Engagement in an Urban Science Classroom, Urban Education, Vol.40, No.4, 446-472, 2005.

[64] J. C. Park. Probeware Tools for Science Investigations, Technology in the Secondary Science Classroom, 33-41, 2008.
[65] R. M. Pringle, K. Dawson, A. D. Ritzhaupt. Integrating Science and Technology: Using Technological Pedagogical Content Knowledge as a Framework to Study the Practices of Science Teachers, Journal of Science Education and Technology, Vol.24, No.5, 648-662, 2015.

[66] Z. Cubukcu, S.B. Tosuntas. Communication in Technology Supported Education Environments: A Classroom Interaction Analysis, Journal of Research in Education and Teaching, Vol.5, No.Special Issue, 192 - 199, 2016.

[67] C. Akay. Teknoloji Temelli Ogretim Tasarimlari Hazırlama ve Uygulama Ilkeleri. T. Yanpar Yelken, H. Sancar Tokmak, S. Ozgelen \& L. Incikabi (Ed.), Fen ve Matematik Egitiminde Teknolojik Pedagojik Alan Bilgisi Temelli Ogretim Tasarimlari (pp.13-34), Ankara, Ani Yayincilik, 2013.

[68] O. Demirel, S. S. Seferoglu, E. Yagc1. Ogretim Teknolojileri ve Materyal Gelistirme, Ankara, Pegem A Yayincilik, 2001.

[69] O. Enonbun. Constructivism and Web 2.0 in the Emerging Learning Era: A Global Perspective, Journal of Strategic Innovation and Sustainability, Vol.6, No.4, 16-25, 2010.

[70] A. Isman. Ogretim Teknolojileri ve Materyal Tasarimi, Ankara, Pegem A Yayincilik, 2013.

[71] S. Sadi Seferoglu. Ogretim Teknolojileri ve Materyal Tasarimi, Ankara, Pegem A Yayincilik, 2015.

[72] M. Simonson, S. Smaldino, M. Albright, S. Zvacek. Teaching and Learning at a Distance. Foundations of Distance Eduucation (Fourth Edition), USA, Prentice Hall, 2003.

[73] Y. Sahin, S. Yildirim. Ogretim Teknolojileri ve Materyal Gelistirme, Ankara, Ani Yayincilik, 1999.

[74] A. Senturk, (2013). Bilgisayarların Ogretimdeki Uygulamalari ve Bilgisayar Destekli Ogretim. M. Saritas (Ed.), Ogretim Teknolojileri ve Materyal Tasarimi (pp.121-131), Ankara, Pegem Yayincilik, 2013.

[75] T. Yanpar Yelken. Ogretim Teknolojileri ve Materyal Tasarimi, Ankara, Ani Yayincilik, 2015.

[76] M. Koskela, P. Kiltti, I. Vilpola, J. Tervonen. Suitability of a Virtual Learning Environment for Higher Education, Electronic Journal of e-Learning, Vol.3, No.1, 23-32, 2005.

[77] T. Bahcekapili. Experiences from Collaboration Between Information Technologies Teacher and Classroom Teacher Candidates Orientated by the Technology-Supported Instruction, Karadeniz Teknik Universitesi Fen Bilimleri Enstitusu, Trabzon, 2011.

[78] H. C. Celik, M. Kahyaoglu. The Cluster Analysis of Primary School Candidate Teachers' Attitudes toward Technology, Turk Egitim Bilimleri Dergisi, Vol.5, No.4, 571-586, 2007.

[79] G. Dagdalan, E. Tas. Effect of Simulation - Based Science Teaching on Students' Achievement and Attitudes towards Computer - Based Science Teaching, Fen Bilimleri Ogretimi Dergisi, Vol.5, No.2, 160 - 172, 2017.

[80] N. Erdemir, H. Bakirci, E. Eyduran. Ogretmen Adaylarinin Egitimde Teknolojiyi Kullanabilme Ozguvenlerinin Tespiti, Turk Fen Egitimi Dergisi, Vol.6, No.3, 100-108, 2009. 
[81] H. Gumusdag, E. Cerit, S. Gonulates, C. Arslanoglu, C. Bastik, S. Sahin, C. Unlu. Determination of Computer Use Competencies and Attitudes of Physical Education Teachers, International Refereed Journal of Humanities and Academic Sciences, Vol.2, No.4, 2013.

[82] A. Karoglu Kocaman. The Changing Nature of Storytelling By Means Of Technology in the Instructional Process: Digital Storytelling, Educational Technology Theory and Practice, Vol.5, No.2, 89-106, 2015.

[83] H. Saka Ozturk. Analyzing the Correlations among the Level of Technopedagogical Content Knowledge of Teachers, self-Efficacy and Academic Success of Student, Unpublished Master Thesis, Necmettin Erbakan Universitesi Egitim Bilimleri Enstitusu, Konya, 2017.

[84] R. L. Linn, N. E. Gronlund. Measurement and Assessment in Teaching ( $8^{\text {th }}$ Edition), New Jersey, Prentice Hall, 2000.

[85] S., Buyukozturk, E. Kilic Cakmak, O. E. Akgun, S. Karadeniz, F. Demirel. Bilimsel Arastirma Yontemleri, Ankara, Pegem A Yayincilik, 2016.

[86] D. Tepe. Relationship between Students Attitudes toward Their Science Lessons and Their Achievement in Science, Unpublished Master Thesis, Marmara Universitesi Fen Bilimleri Enstitusu, Istanbul, 1999.

[87] S. Buyukozturk. Sosyal Bilimler icin Veri Analizi El Kitabi, Istatistik, Arastirma Deseni, SPSS Uygulamalari ve Yorum, Ankara, Pegem A Yayincilik, 2016)

[88] J. Cohen. Statistical Power Analysis for the Behavioral Sciences, Hillsdale, NJ, Lawrence Earlbaum Associates, 1988.

[89] J. Sim, C. Wright. Research in Health Care: Concepts, Designs and Methods, United Kingdom, Cheltenham, Nelson Thornes Ltd., 2002.

[90] N. Koklu, S. Buyukozturk, O. Cokluk Bokeoglu. Sosyal Bilimler icin İstatistik, Ankara, Pegem A Yayincilik, 2006.

[91] B. G. Tabachnick, L. S. Fidell. Using Multivariate Statistics (6 $6^{\text {th }}$ Edition), Boston, Pearson, 2013.

[92] H. Akcay, C. Tuysuz, B. Feyzioglu. Bilgisayar Destekli Fen Bilgisi Ogretiminin Ogrenci Basarisina ve Tutumuna Etkisine Bir Ornek: Mol Kavrami ve Avogadro Sayisi, The Turkish Online Journal of Educational Technology, Vol.2, No.2, 57-66, 2003.

[93] Y. Kara, S. Yesilyurt. The Research on the Effect of the Tutorial Software on Students' Achievements, Misconceptions and Attitudes towards Biology on the Cell Division Subject, Cukurova University Faculty of Education Journal, Vol.3, No.34, 41-49, 2007.

[94] B. Ogreten, S. Ulucinar Sagir. The Effect of Interactive Teaching on Academic Success and Technology Course for $4^{\text {th }}$ Grades, Bati Anadolu Egitim Bilimleri Dergisi, Vol.4, No.3, 1-18, 2013

[95] A. Kumas. The Evaluation of Innovative, Technology Supported, Enriched Teacher Guide Materials Developed According to REACT Instructional Strategy of Teaching Physics, Unpublished Doctoral Dissertation, Karadeniz Teknik Universitesi Egitim Bilimleri Enstitusu, Trabzon, 2015.
[96] S. Pekmezci. Effects of Short Stories Reinforced With Information Technology on Students' Success, Their Self Efficacy and Their Attitudes towards Science, Unpublished Master Thesis, Pamukkale Universitesi Egitim Bilimleri Enstitusu, Denizli, 2014.

[97] O. Guler. Using Interactive 3 Dimensional Technologies in Education and Application of the Information Technology Lessons, Unpublished Master Thesis, Gazi Universitesi Bilisim Enstitusu, Ankara, 2014.

[98] V. Demirer. Use of E-storytelling in Primary Education and its Effects, Unpublished Doctoral Dissertation, Necmettin Erbakan Universitesi, Konya, 2013.

[99] G. Sakiz, B. Ozden, D. Aksu, O. Simsek. The Effect of the Use of Interactive Whiteboard on Students' Achievement and Attitude toward Instruction in Science and Technology Classrooms, Ataturk Universitesi Sosyal Bilimler Enstitusu Dergisi, Vol.18, No.3, 257-274, 2014.

[100] C.H. Chen, B. Howard. Effect of Live Simulation on Middle School Students' Attitudes and Learning toward Science, Educational Technology \& Society, Vol.13, No.1, 133-139, 2010.

[101] H. Ertepinar, H. Demircioglu, O. Geban, D. Yavuz. The Effect of Assimilation and Computer Based Instruction to Understand Mole Concept, III. National Science Education Symposium, Karadeniz Technical University, Turkey, 1998.

[102] Z. Kirbag Zengin, G. Kirilmazkaya, G. Kececi. Akilli Tahta Kullaniminin Ogrencilerin Fen ve Teknoloji Dersindeki Basari ve Tutuma Etkisi, $5^{\text {th }}$ International Computer and Instructional Technologies Symposium, 22-24 Eylul, Elazig: Firat Universitesi, 2011.

[103] M. Frailich, M. Kesner, A. Hofstein. The Influence of Web Based Chemistry Learning on Students Perceptions, Attitudes and Achievement, Research in Science and Technological Education, Vol.25, No.2, 179-197, 2007.

[104] T. Jose, V. Williamson. Molecular Visualization and Science Education: An Evaluation of the NSF-Sponsored Workshop, Journal of Chemical Education, 82, 937-943, 2005.

[105] N. Selwyn. Students' Attitudes towards Computers in Sixteen to Nineteen Education, Education and Information Technologies, Vol.4, No.2, 129-141, 1999.

[106] S.P. Stokes. Satisfaction of College Student with the Digital Learning Environment: Do Learners' Temperaments Make a Difference? The Internet and Higher Education, Vol.4, No.1, 31-44, 2001

[107] L.R. Winer, S. Cooperstook. The "Intelligent Classroom": Changing Teaching and Learning with an Evolving Technological Environment, Computer \& Education, Vol.38, 253-266, 2001.

[108] C. Kim, A. L. Baylor. A Virtual Change Agent: Motivating Pre-Service Teachers to Integrate Technology in Their Future Classrooms, Journal of Educational Technology \& Society, Vol.11, No.2, 309-321, 2008.

[109] S. Akcay, M. Aydogdu, H.I. Yildirim, O. Sensoy. Ilkogretim 6. Siniflarda Bilgisayar Destekli Ogretimin Ogrencilerin Fen Bilgisi Dersine ve Bilgisayara Yonelik Tutumlarina Etkisi, XIV. Ulusal Egitim Bilimleri Kongresi, 
28-30 Eylul 2005, Pamukkale Universitesi Egitim Fakultesi, Denizli, 2005.

[110]A. Y. Altunay. The Effects of the Material That Are Prepared As Concept Map by Computer Environment to Success of Primary School Students in Science Lesson, Unpublished Master Thesis, Selcuk Universitesi Fen Bilimleri Enstitusu, Konya, 2006.

[111]B. Inan. Effects of Computer Based Education on Secondary School Sixth Grade Student's Science Course Success and Attitudes, Unpublished Master Thesis, Nigde Universitesi Egitim Bilimleri Enstitusu, Nigde, 2015.

[112] N. Ozabaci, A. Olgun. A Study on Computer Based Science and Technology Education on Students' Attitudes, Master Learning Skills and Achievement, Electronic Journal of Social Sciences, Vol.10, No.37, 93-107, 2011.

[113] N. Yenice. Bilgisayar Destekli Fen Bilgisi Ogretiminin Ogrencilerin Fen ve Bilgisayar Tutumlarina Etkisi, The Turkish Online Journal of Educational Technology, Vol.2, No.4, 79-85, 2003.

[114] S. Aycan, E. Ari, S. Turkoguz, H. Sezer, U. Kaynar. Fen ve Fizik Ogretiminde Bilgisayar Destekli Simulasyon Tekniginin Ogrenci Basarilarina Etkisi: Yeryuzunde Hareket Ornegi, M.U. Ataturk Egitim Fakultesi Egitim Bilimleri Dergisi, Vol.15, 57-70, 2002.
[115] A. Arslan. Affection of the Turkish Instruction in Support of Computer Method to the Attitudes of the Students of Turkish Lesson, E-Journal of New World Sciences Academy, Vol.4, No.2, 665-677, 2009.

[116]O. Curaoglu. The Effects of Technology Enriched Instruction on $6^{\text {th }}$ Grade Public School Students' Attitudes And Problem Solving Skills in Mathematics, Unpublished Doctoral Dissertation, Orta Dogu Teknik Universitesi Fen Bilimleri Enstitusu, Ankara, 2012.

[117] A. T. Oner. The Effect of Technology Assisted Instruction in Algebra Instruction for the Seventh Grade Students on the Students? Achievement, Attitude and its Retention, Unpublished Master Thesis, Dokuz Eylul Universitesi Egitim Bilimleri Enstitusu, İzmir, 2009.

[118] S. Cepni, E. Tas, S. Kose. The Effects of Computer Assisted Materials on Students' Cognitive Levels, Misconceptions and Attitude toward Science, Computers and Education, Vol.46, 192-205, 2006.

[119] O. Kahraman. Effect of the Computer Assisted Instruction on Student? Attitude and Achievement on the Physics Topic of the $7^{\text {th }}$ Grade Science Lesson, Unpublished Master Thesis, Pamukkale Universitesi Fen Bilimleri Enstitusu, Denizli, 2007. 